\title{
Detection of OmpA gene by PCR for specific detection of Salmonella serovars
}

\author{
Joy. L. Kataria ${ }^{1}$, A. Kumar ${ }^{2}$, S. Rajagunalan ${ }^{3}$, L. Jonathan ${ }^{4}$ and R.K. Agarwal ${ }^{5}$
}

1. Division of Veterinary Public Health, Indian Veterinary Research Institute, Izatnagar, Bareilly, Uttar Pradesh, India. E-mail: jluvjkat@gmail.com; 2. Division of Veterinary Public Health, Indian Veterinary Research Institute, Izatnagar, Bareilly, Uttar Pradesh, India. E-mail: ashokakt@rediffmail.com; 3. Division of Veterinary Public Health, Indian Veterinary Research Institute, Izatnagar, Bareilly, Uttar Pradesh, India. E-mail: drgunavet@gmail.com; 4. Division of Animal Biotechnology, Indian Veterinary Research Institute, Izatnagar, Bareilly, Uttar Pradesh, India. E-mail:

jonathan.Ialsiamthara@gmail.com; 5. Division of Veterinary Bacteriology and Mycology, Indian Veterinary Research Institute, Izatnagar, Bareilly, Uttar Pradesh, India. E-mail: grace_bly@yahoo.com

Received: 14-08-2013, Revised: 10-09-2013, Accepted: 11-09-2013, Pub̄lished online: 23-10-2013

doi: $10.14202 /$ vetworld.2013.911-914

How to cite this article: Kataria J L, Kumar A, Rajagunalan S, J onathan L and Agarwal RK (2013) Detection of OmpA gene by PCR for specific detection of Salmonella serovars, Veterinary World 6(11): 911-914.

\begin{abstract}
Aim: The study was carried out to determine the sensitivity and specificity of OmpA gene in Salmonella serovars through PCR.

Materials and Methods: A set of primers were designed targeting the OmpA gene specific for the Salmonella and polymerase chain reaction was standardized using Salomonella Typhimurium as a positive control and as a negative control 4 non salmonella cultures such as Campylobacter coli, Arcobacter butzleri, Brucella abortus and E. coli. Sensitivity of the test was determined by serial dilution of genomic DNA of standard $S$. Typhimurium. The PCR standardized was used for screening 68 strains of different serovars of Salmonella.
\end{abstract}

Results: The PCR developed targeting OmpA specific for Salmonella was highly specific in detection of the salmonella serovar alone and sensitivity was upto $68.8 \mathrm{fg}$. A total of 68 virulent/ natural strains of different serovars of salmonella taken up for the study were positive by $O m p A$ based PCR.

Conclusions: This study reports that, OmpA gene which is conserved among Salmonella serovars can be used for the detection of Salmonella in food or clinical samples in further studies, with high sensitivity and specificity.

Key words: OmpA, PCR, Salmonella

\section{I ntroduction}

Salmonella is a food-borne pathogen that is typically acquired through consumption of contaminated food and water [1]. Salmonellosis continues to be a major public health problem worldwide. It also contributes to negative economic impacts due to the cost of surveillance investigation, treatment and prevention of illness [2]. The global burden of human gastroenteritis due to Salmonella has been estimated 93.8 million cases, resulting in 155,000 deaths each year [3]. Poultry is considered a major reservoir for many non-host specific motile serovars of Salmonella, and often human infection is attributed to consumption of contaminated poultry products, such as eggs and meats [4].

The outer membrane protein (OMPs) of Gramnegative bacteria plays a major role in the adaptation of the bacterium to its various external environments, by passively and/ or selectively controlling influx and efflux of important solutes, peptides or proteins, nucleic acids, and other organic compounds such as lipids and polysaccharides [5]. Most OMPs are surface exposed and, therefore, are potentially important in

Copyright: The authors. This article is an open access article licensed under the terms of the Creative Commons Attribution License (http://creativecommons.org/licenses/by/2.0) which permits unrestricted use, distribution and reproduction in any medium, provided the work is properly cited. interfacing bacteria with the mammalian host and its defenses, bacteriophages, and other bacteria or microorganisms [6]. The outer membrane proteins comprise almost $50 \%$ of the bacterial membranes of Gram negative bacteria [7].

OmpA super family is one of the most abundant outer membrane proteins in prokaryotes and is most widely studied [8]. Its main role is to provide integrity to the membrane by ensuring physical linkages between the outer membrane and the underlying peptidoglycan layer as well as having importance in bacterial conjugation $[9,10]$. It also serves as a receptor to some of the bacteriophages [11] and colicins [12]. Of all the OMPs, OmpA appears to be a major antigenic protein in Salmonella induced $\mathrm{ReA} / \mathrm{uSpA}$, as it is common to most of the stimulatory fractions [13].

Salmonella $\operatorname{OmpA}$ is immunostimulatory as demonstrated by stimulation of IFN-g production and enhanced expression of MHC and costimulatory molecules in dendritic cells and/or T cells and may play a role in modulation of the immune response against salmonellosis $[14,15]$.

Traditional culture-based methods for detecting Salmonella are reliable but labor-intensive and timeconsuming, demanding several days for a definitive result. Immunoassays such as enzyme-linked immunosorbent assay (ELISA) have been developed for 
Table-1. PCR results for different Salmonella serotypes targeting OmpA gene

\begin{tabular}{|c|c|c|c|}
\hline Sr.No & Species & Culture No. & Results \\
\hline $1-17$ & S.Typhimurium & $\begin{array}{l}\text { E-4630, E-73, E-4629, E-275, E-366, E-159, E-2622, E-456, E-2375, E-4741, E-270, E-277, E-364, } \\
\text { E-2416, E-2393, E-4810, E-2395 }\end{array}$ & All + \\
\hline $\begin{array}{l}18-29 \\
30-32\end{array}$ & $\begin{array}{l}\text { S. Enteritidis } \\
\text { S. Pullorum }\end{array}$ & $\begin{array}{l}\text { E-74, E-79, E-161, E-2475, E-2473, E-2465, E-20, E-2477, E-4252, E-2478, E-2477, E-2472 } \\
\text { E-154, E-153, E-152 }\end{array}$ & $\begin{array}{l}\text { All }+ \\
\text { All }+\end{array}$ \\
\hline $33-43$ & S. Gallinarum & E-85, E-4668, E-4661, E-2634, E-77, E-75, E-4045, E-76, E-4685, E-76 & All + \\
\hline 44 & S. Anatum & E-907 & + \\
\hline 45 & S. Alachera & E-65 & + \\
\hline 46 & S. 6,7:Y & E-62 & + \\
\hline 47 & S. Bredeney & $\mathrm{E}-85$ & + \\
\hline 48 & S. Abortus equi & $\mathrm{E}-01$ & + \\
\hline 49 & S. Italiana & E-104 & + \\
\hline 50 & S. Aviatum & $E-1059$ & + \\
\hline 51 & S. Virginia & $E-60 c$ & + \\
\hline 52 & S. Rough & $\mathrm{E}-1101$ & + \\
\hline 53 & S. Paratyphi B & E-801 & + \\
\hline 54 & S. Shipley & $\mathrm{E}-150$ & + \\
\hline 55 & S. Rubislav & $\mathrm{E}-47$ & + \\
\hline 56 & S. Bonariensis & $E-84$ & + \\
\hline 57 & S. Tennessee & E-56a & + \\
\hline 58 & S. Derby & $\mathrm{E}-68$ & + \\
\hline 59 & S. Weslaeo & $E-64$ & + \\
\hline 60 & S. Dahlem & E-712 & + \\
\hline 61 & S. Canada & $E-3540$ & + \\
\hline 62 & S. Heidelberg & $E-3716$ & + \\
\hline 63 & S. Lindenburg & E-3772 & + \\
\hline 64 & S. Poona & $E-1565$ & + \\
\hline 65 & S. Shipley & $E-150$ & + \\
\hline 66 & S. Bareilly & E-189 & + \\
\hline 67 & S. Wein & $E-3636$ & + \\
\hline 68 & S. Mons & E-3695 & + \\
\hline 69 & C. jejuni & -- & \\
\hline 70 & B. abortus & -- & \\
\hline 71 & A. butzleri & -- & \\
\hline 72 & E. coli & -- & \\
\hline
\end{tabular}

Salmonella detection, however, low specificity has limited their use [16].

PCR technology represents a rapid procedure with high sensitivity and high specificity to detect Salmonella in a wide variety of food. Several PCR assays have been developed by targeting various Salmonella genes, such as 16S rRNA, agfA, and viaB and virulence-associated plasmids [17].

The study was thus, focused on polymerase chain reaction based amplification of $O m p A$ gene to prove its conserved nature in Salmonella serovars and to evaluate its specificity and sensitivity in detection.

\section{Materials and Methods}

A total of 68 Salmonella strains and 4 strains of non- Salmonella cultures (Table-1) were used in this study. Salmonella and non-Salmonella cultures were obtained from repositories of National Salmonella Centre, Division of Bacteriology and Mycology and Viral Zoonoses Laboratory, Division of Veterinary Public Health, I.V.R.I. All the cultures mentioned in Table-1 were revived, tested for their purity, morphology and biochemical characteristics as per standard protocol [18].

PCR amplification and detection: The sequence of the primers used is as follows: Forward: 5'-AGT CGA GC TCATGAAAAAGACAGCTATCGC-3' Reverse: 5'AGTCAAGCTTTTAAGCCTGCGGCTGAGTTA-3'.

DNA extraction and quantification: Oligonucleotide primers were designed targeting the OmpA gene of Salmonella serovar based on the nucleotide sequence available in the Genbank and the primers were got synthesized commercially.
The genomic DNA from the reference strain $S$. Typhimurium was extracted by phenol chloroform method [19] and checked for quality and quantity spectrophotometerically, while, the genomic DNA from the other salmonella and non- salmonella isolates were extracted by snap chill method. Briefly, $1 \mathrm{~mL}$ of the overnight incubated cultures was boiled in boiling water for 10 minutes and immediately transferred onto ice. For PCR assay, $2 \mu \mathrm{L}$ of this heated broth was taken as template.

Detection of OmpA gene by PCR: The PCR mixture of $25 \mu 1$ contained $2.5 \mu \mathrm{L}$ of Dream taq buffer, $2.5 \mu \mathrm{L}$ of $\mathrm{dNTP}(2 \mathrm{mM}), 10 \mathrm{pM}$ each of forward and reverse primer for OmpA gene and 1.0 U of Dream taq DNA polymerase and $2.0 \mu \mathrm{l}$ of template DNA. The PCR reaction was performed in a thermal cycler (BIOER, USA) using the following standard cycling procedure: an initial denaturation at $95^{\circ} \mathrm{C}$ for $5 \mathrm{~min}$, followed by 34 cyclesof denaturation at $94^{\circ} \mathrm{C}$ for 1 minute, primer annealing at $55^{\circ} \mathrm{C}$ for 1 minute and extension at $72^{\circ} \mathrm{C}$ for 1 minute and a final extension at $72^{\circ} \mathrm{C}$ for 10 min.Amplified products were analysed by agarose gel (1\% in $1 \mathrm{X}$ TBE) electrophoresis at $5 \mathrm{v} / \mathrm{cm}$ for $2 \mathrm{~h}$ and finally documented using gel documentation system (UVP).

PCR specificity and sensitivity: PCR specificity and sensitivity was determined using all the pure cultures lysate (Table-1). The specificity of OmpA primers was determined by PCR and observed for any product generated from other bacteria. For determination of sensitivity of the PCR assay, the DNA was diluted ten fold and the ability of this PCR assay to detect the minimum concentration of DNA was determined and 
assay was repeated thrice to confirm its repeatability.

\section{Results}

PCR was standardised for the amplification of $O m p A$ gene by optimizing reaction mixture and cycling conditions using the genomic DNA from standard $S$. Typhimurium extracted and purified by phenol: chloroform method. Standardized PCR yielded the expected single band of $1053 \mathrm{bp}$ on agarose gel electrophoresis. The size for PCR product was as per the expected size of the primers which were designed to amplify the OmpA gene.

A total of 68 isolates were screened for the presence of $O m p A$ gene and it was found that all the Salmonella isolates were positive for the presence of OmpA gene and non of the non Salmonella cultures were positive for OmpA gene ( Table-1).

The concentration of the genomic DNA from the reference $S$. Typhimurium was $3240 \mathrm{ng} / \mu \mathrm{L}$ and the minimum detection limit (sensitivity) of the PCR was found that upto $64.8 \mathrm{fg}$ DNA template which produced a clearly visible PCR band of $1053 \mathrm{bp}$. The band of $1053 \mathrm{bp}$ in the lane 8 was clearly visible whereas the band in the lane 9 was faint and was difficult to appreciate (Fig-1).

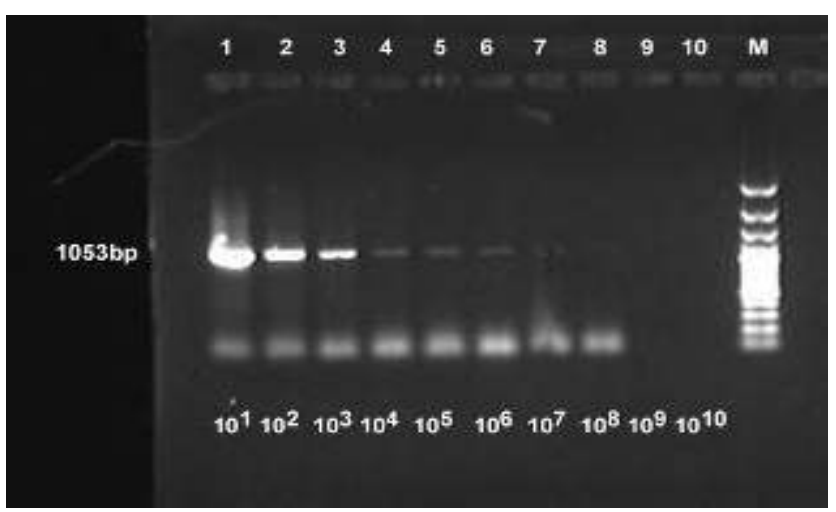

Figure-1. Sensitivity of OmpA PCR after tenfold dilution of genomic DNA of S.Typhimurium.

\section{Discussion}

Salmonella are widely distributed in nature and they survive well in a variety of foods. Poultry, eggs and dairy products are the most common vehicle of salmonellosis. In recent years, fresh produce like fruits and vegetables have gained concern as vehicles of transmission where contamination can occur at multiple steps along the food chain [20].

$O m p A$ functions in the bacterial structure, physiology, and adaptation to environmental stresses, whereas in disease they can serve as virulence factors causing adhesion, invasion and damage of host tissue or evasion of host defences resulting in clinical disease or death [5].

The development of molecular methods for diagnosis of infectious diseases has improved the sensitivity, specificity, quality and availability of diagnosis and treatment. Several polymerase chain reaction (PCR) assays for detection of Salmonella have been developed, and different targets DNAs for amplification have been applied [21].

A total of 68 isolates were screened for the presence of $O m p A$ gene and it was found that all the Salmonella isolates were positive for the presence of OmpA gene. Our results were in confirmation with Freudl and Cole [22] who reported that $O m p A$ regulatory region of $S$. Typhimurium is highly conserved and has an overlapping twin-promoter arrangement. In addition, Okamura et al [23] based on bioinformatic analysis also reported that OmpA is well conserved among the various Salmonella serovars.

\section{Conclusion}

From the overall study, it can be concluded that OmpA gene is conserved among Salmonella serovars. Since our preliminary study proved the conserved nature of gene in different Salmonella serovars, this may be used for the detection of Salmonella in food or clinical samples in further studies.

\section{Author's contributions}

JLK, SR and JL planned and designed the study. RKA provided the salmonella serovars and AK provided the non Salmonella cultures. The experiment was performed by JLK and JL. JLK and SR drafted and revised the manuscript. All authors read and approved the final manuscript.

\section{Acknowledgements}

The authors are highly thankful to Director, Indian Veterinary Research Institute, Bareilly for providing necessary funds and facilities to carry out the investigation.

\section{Competing interests}

The authors declare that they have no competing interests.

\section{References}

1. Nakano, M., Yamasaki, E., Ichinose, A., Shimohata, T., Takahashi, A., Akada. J. K., Nakamura, K., Moss, J., Hirayama, T. and Kurazono, H. (2012) Salmonella enterotoxin (Stn) regulates membrane composition and integrity. Dis Model Mech.5:515-521.

2. Pui, C.F., Wong, W.C., Chai, L.C., Tunung, R., Jeyaletchumi, P., Noor Hidayah, M.S., Ubong, A., Farinazleen, M.G., Cheah, Y.K. and Son, R. (2011) Salmonella: A foodborne pathogen. Int. F. Res. J. 18: 465-473.

3. Majowicz, S.E., Musto, J., Scallan, E., Angulo, F.J., Kirk, M., O'Brien, S.K., Jones, T.F., Fazil, A. and Hoekstra, R.M. (2010) The global burden of non typhoidal Salmonella gastroenteritis. Clin. Infect. Dis. 50: 882-889.

4. Barua, H., Biswas, P.K., Olsen, K.E.P,. Shil, S.K. and Christensen, J.P. (2013) Molecular Characterization of Motile Serovars of Salmonella enterica from Breeder and Commercial Broiler Poultry Farms in Bangladesh. PLoS One 8(3): e57811.

5. Confer, A.W. and Ayalew, S. (2013) The OmpA family of proteins: Roles in bacterial pathogenesis and immunity. Vet. Microbiol. 163: 207-222.

6. Krishnan, S. and Prasadarao, N.V. (2012) Outer membrane protein $\mathrm{A}$ and $\mathrm{OprF}-$ versatile roles in Gram-negative bacterial infections. FEBS J. 279:919-930.

7. Koebnik, R., Locher, K.P. and Van, Gelder P. (2000) Structure and function of bacterial outer membrane proteins: 
barrels in a nutshell. Mol. Microbiol.37: 239-253.

8. Thanassi, D. G. and Hultgren, S. J. (2000) Multiple pathways allow protein secretion across the bacterial outer membrane. Curr. Opin. Cell. Biol. 12: 420-430.

9. Skurray, R.A. and Reeves, P. (1974) F factor mediated immunity to lethal zygosis in Escherichia coli K-12. J. Bacteriol. 117: 100-106.

10. Reid, G. and Henning, U. (1987) A unique amino acid substitution in the outer membrane protein OmpA causes conjugation deficiency in Escherichia coli K -12. Febs. Lett. 223(2): 387-390.

11. Morona, R., Kramer, C. and Henning, U. (1985) Bacteriophage receptor area of outer membrane protein OmpA of Escherichia coli K -12. J. Bacteriol.164 (2):539-599.

12. Foulds, J. and Barrett, C. (1973) Characterization of Escherichia coli mutants tolerant to bacteriocins JF246-2: New classes of tolerant mutants. J. Bacteriol. 116: 885-892.

13. Singh, R., Shasany, A.K., Aggarwal, A., Sinha, S., Sisodia, B. S., Khanuja, S.P. S. and Misra, R. (2007) Low molecular weight proteins of outer membrane of Salmonella typhimurium are immunogenic in Salmonella induced reactive arthritis revealed by proteomics. Clin and Expt Immuno, 148: 486493.

14. Jang, M.J., Kim, J.E., Chung, Y.H., Lee, W.B., Shin, Y.K., Lee, J.S., Kim D. and Park, Y.M. (2011) Dendritic cells stimulated with outer membrane protein $\mathrm{A}(\mathrm{OmpA})$ of Salmonella typhimurium generate effective anti-tumor immunity. Vaccine 29: 2400-2410.

15. Lee, J.S., Jung, I.D., Lee, C.M., Park, J.W., Chun, S.H., Jeong, S.K., Ha, T.K., Shin, Y.K., Kim, D.J. and Park, Y.M. (2010) Outer membrane protein a of Salmonella enterica serovar Typhimurium activates dendritic cells and enhances
Th1 polarization. BMC Microbiol. 10:263.

16. Chen, S., Wang, F., Beaulieu, J.C., Stein, R.E. and Ge, B. (2011) Rapid Detection of Viable Salmonellae in Produce by Coupling Propidium Monoazide with Loop Mediated Isothermal Amplification. Appl. Environ. Microbiol. 77: 4008.

17. Loongyai, W., Promphet, K., Kangsukul, N. and Noppha, R. (2010) Detection of Salmonella in Egg Shell and Egg Content from Different Housing Systems for Laying Hens. Wld.Acad. Sci. Engg. Tech. 41: 121-123.

18. Agarwal, R.K., Bhilegaonkar, K.N., Singh, D.K., Kumar, A. and Rathore, R.S. (2003) In: Laboratory Manual for the Isolation and Identification of Foodborne Pathogens. Indian Veterinary Research Institute, Izatnagar, Bareilly, India. p.100.

19. Sambrook, J. and Russel, D.W. (2001) In: Molecular cloning, a laboratory manual, Volume I, II, III. $3^{\text {rd }}$ edition, CSHL press (USA).

20. Bouchrif, B., Paglietti, B., Murgia, M., Piana, A., Cohen, N., Ennaji, M., Rubino, S. and Timinouni, M. (2009) Prevalence and antibiotic-resistance of Salmonella isolated from food in Morocco. J. Inf. Dev. Count. 28: 35-40.

21. Radji, M., Malik, A. and Widyasmara, A. (2010) Rapid detection of Salmonella in food and beverage samples by polymerase chain reaction. Malay. J. Microbiol. 2: 166-170.

22. Freudl, R. and Cole, S.T. (1983) Cloning and molecular characterization of the ompA Gene from Salmonella typhimurium. Eur. J. Biochem. 134: 497- 502.

23. Okamura, M., Ueda, M., Noda, Y., Kashimoto, T., Takehara, K. And Nakamura, M. (2012) Immunization with outer membrane protein from Salmonella enterica serovar Enteritidis induces humoral immune response but no protection against homologus challenge in chickens. Poult. Sci. 91(10): 2444-9. 